\title{
How human capital interacts with the early development of academic spin-offs
}

\author{
Sven de Cleyn, Johan Braet and Magnus Klofsten
}

\section{Linköping University Post Print}

\section{Tweet}

N.B.: When citing this work, cite the original article.

The original publication is available at www.springerlink.com:

Sven de Cleyn, Johan Braet and Magnus Klofsten, How human capital interacts with the early development of academic spin-offs, 2015, The International Entrepreneurship and Management Journal, (11), 3, 599-621.

http://dx.doi.org/10.1007/s11365-013-0294-Z

Copyright: Springer Verlag (Germany) http://www.springerlink.com/?MUD=MP

Postprint available at: Linköping University Electronic Press

http://urn.kb.se/resolve?urn=urn:nbn:se:liu:diva-103488 


\title{
How human capital interacts with the early development of academic spin-offs
}

\author{
Sven H. De Cleyn • Johan Braet • Magnus Klofsten
}

Published online: 8 January 2014

(C) Springer Science+Business Media New York 2014

\begin{abstract}
This paper focuses on venture team characteristics with respect to human capital dimensions in early stage ventures emerging from academic research (institutions). Three major groups have been investigated: founders, top managers and directors. Data was obtained using personal interviews with 185 product-oriented academic spin-offs in nine European countries, including those of 17 failures. The results show a significant positive - but diminishing - impact of team heterogeneity on venture success, as well as a positive impact from legal expertise within the board of directors. At management level, the results further indicate that larger management team are better equipped to face the challenges in academic spin-offs. Furthermore, the added value of serial entrepreneurs is questioned, since they seem to negatively impact a spin-off's survival chances. Several implications are addressed, dealing with an appropriate team composition (on the levels of both top management and the board of directors) as well as the importance of paying attention to team development.
\end{abstract}

Keywords Academic spin-offs · Human capital · Team characteristics · Early development $\cdot$ Failure $\cdot$ Survival

\section{Introduction}

Since the Bayh-Dole Act was passed in the U.S. in 1980 (this was followed by similar changes in the legislative framework in most European countries in the 1990s), attention to academic entrepreneurship has continued to increase. One of the most visible ways of transferring technology to society and the marketplace is through the

S. H. De Cleyn $(\bowtie) \cdot J$. Braet

Faculty of Applied Economics, University of Antwerp, Prinsstraart 13, BE-2000 Antwerp, Belgium e-mail: sven.decleyn@uantwerpen.be

J. Braet

e-mail: Johan.braet@uantwerpen.be

M. Klofsten

Department of Management and Economics, Linköping University, SE-581 83 Linköping, Sweden e-mail: magnus.klofsten@liu.se 
creation of academic spin-offs (ASOs; see Klofsten and Jones-Evans 2000; Klofsten et al. 1999; Rasmussen et al. 2006; Shane and Stuart 2002; Vohora et al. 2004). In Silicon Valley, ASOs have become the main technology transfer mechanism (Carayannis et al. 1998), although in many other regions the use of ASOs is still in its infancy (Pirnay et al. 2003).

Similar to any other start-ups, new ASOs face a number of challenges and risks inherent to their early development process (Song et al. 2008). The main risks stem from the absence of a past track record and of a resource buffer at a venture level (Davidsson and Klofsten 2003; De Coster and Butler 2005; Lerner 2005), which are closely connected to the liabilities of newness/adolescence and smallness (Stinchcombe 1965; Brüderl and Schussler 1990; Fichman and Levinthal 1991). The absence of a prior track record for a venture often hampers their ability to obtain sufficient resources (Wright et al. 2006; Harrison et al. 2004), as this absence forces external entities to base their assessment mainly on the characteristics of the key persons (Ostgaard and Birley 1996) in terms of human as well as social capital. The characteristics of the key persons - in terms of their education, work and entrepreneurial experience and social relations - thus become a major source of credibility and legitimacy (Reagans and Zuckerman 2001; Packalen 2007). Furthermore, these key persons play a crucial role in the early development of the venture (Shrader and Siegel 2007). The key persons for a venture are the founders, the top management team (TMT) and/or the board of directors (BoD).

Despite the relatively large attention in prior literature on human capital issues, a number of topics have been under-researched. Given the specific nature of ASOs as described above, few scholars have investigated team characteristics and their impact on the survival likelihood of early stage ASOs. This study then adds both on the ASOs aspect (as compared to other technology-based ventures), as well as on the early stage aspect (most studies focus on growth stages). Additionally, few studies take team evolvement over a longer period of time into account. This study adds to current literature by evaluating the effects of different team characteristics over time.

The aim of this study is to further explore the relationships between human capital aspects of early-stage ASOs and their survival likelihood. After a literature review of prior studies on this subject, "Research framework" deals in detail with the research scope and research questions addressed. The same section provides more insights into the contribution of this study to theory and practice.

\section{Literature review: human capital and ASOs}

Early studies make a clear distinction between human capital and social capital (Davidsson and Honig 2003): human capital refers to the knowledge and experience of individuals (Schultz 1961; Watson et al. 2003), whereas social capital relates to the ability to extract resources (e.g. information or financing) from the external network (Nahapiet and Ghoshal 1998).

Human capital refers to an individual's knowledge, skills, abilities and experiences, which increase knowledge accumulation and business acumen (Schultz 1961; Kaasa 2009; Unger et al. 2011). Human capital can be increased through education, training, and other experiences (Schultz 1961; Gimeno et al. 1997; Kaasa 2009). Higher initial human capital endowments at start-up have been demonstrated to increase the likelihood of a new 
venture's survival (Wetter and Wennberg 2009). Furthermore, Human Capital Theory (HCT) argues that firms with higher human capital should better be able to plan, solve problems, and respond to the challenges imposed by the environment in which they operate (Florin et al. 2003). The contribution of human capital to (new) venture success runs via various mechanisms, and as such, human capital is considered to be resource that can directly affect the achievement of a (sustainable) competitive advantage (Schultz 1961; Coleman 1988). Furthermore, as human capital serves as main source of a start-up's credibility and legitimacy (Ostgaard and Birley 1996; Pennings et al. 1998; Packalen 2007), higher human capital stocks lead to a significantly improved ability to attract resources (Pennings et al. 1998; Delmar and Shane 2004; Packalen 2007). In this regard, Delmar and Shane (2004) have argued that credibility and legitimacy of a venture are most critical in the earliest development stages, since "disbanding depends most on the perceptions of external stakeholders, rather than on actual financial performance" (p. 388). According to Drori et al. (2009), legitimacy stems from a venture possessing advantages over others; in the earliest development stages human capital characteristics are one of the few variables available to assess this advantage (Ostgaard and Birley 1996). As such, credibility and legitimacy stems (largely) from human capital. Another effect of human capital is also indirect: higher levels of human capital usually lead to higher earnings at personal level, which makes start-ups founded by people with higher human capital endowments less vulnerable to financial constraints (i.e. possible constraints in firm development; Colombo and Grilli 2005).

In new ASOs, like in any start-up, the amount of resources is limited and a significant part of the start-up's value is therefore determined by its human capital stock (Shrader and Siegel 2007). Although employees - if any-make up an important part of a firm's human capital stock, in the early stages of ASOs the venture almost always coincides with the founding team and/or the TMT (Colombo and Grilli 2005; Packalen 2007; Shrader and Siegel 2007). Chief executive officers (CEOs) of new ASOs should be able to understand the technology and develop the business proposition for this technology (Clarysse and Moray 2004). This combination of skills, knowledge, and expertise is difficult to find in academic researchers (Franklin et al. 2001; Mosey and Wright 2007), which makes them often less suited to fulfil the challenging task. Especially in new ventures, the human capital stock can be increased by making use of additional sources of human capital, such as a board of directors, advisory board, external advisors, science park managers and, in the case of ASOs, technology transfer offices (TTOs; Nicolaou and Birley 2003). An additional source of human capital (and one that is increasingly used in high-tech start-ups) can be obtained by attracting experienced (serial) entrepreneurs to strengthen the key persons (Rosenblatt and Thelen 1997; George et al. 2010). Recent research by Parker (2013) has, however, indicated that the benefits that serial entrepreneurs contribute venturing disappear over time. Furthermore, through entrepreneurial euphoria, the pros of serial entrepreneurs are sometimes over-emphasized in relation to the cons (Cooper et al. 1995). Overall, prior research has indicated that team formation currently fails in most ASOs (Ensley and Hmieleski 2005): i.e. most ASO teams are too technically-oriented, which increases the need for a better understanding of the effect of human capital in new ventures on their subsequent performance. For a recent in-depth meta-analysis of the relationship between human capital and (new) venture success, see Unger et al. (2011). 


\section{Research framework}

\section{Aim and scope}

Despite the existence of numerous studies on human capital-related issues in new ventures development, we believe that there is room for new studies in this research field. This is based on various reasons, and these can, on the most part, be placed into three categories: academic spin-offs (and the individuals behind the venture), policyrelated matters, and the response of academia.

Firstly, an academic spin-off at foundation is a collection of individuals with almost no accrued knowledge at firm level (Ostgaard and Birley 1996). This situation makes the human capital of the individual key people a key resource for converting codified and tacit knowledge into commercial products and services (Mosey and Wright 2007; Wright et al. 2007). This human capital and the management thereof are heavily context and time-related, due to factors including the increasing complexity of technology and markets and the shift towards an information society (Barney 1991; Schuller and Field 1998; Unger et al. 2011).

Secondly, at both the EU and individual country levels there is a need to develop accurate policies that inspire, foster, and facilitate entrepreneurial behaviour in the society. Several studies, including these on the GEM data, have shown that most European countries are consistently lagging behind the U.S. when it comes to entrepreneurial attitude, culture, and entrepreneurial outcomes (Klofsten and Jones-Evans 2000; Goldfarb and Henrekson 2003). In response to this lack of entrepreneurship in Europe, the EU Commission has undertaken a number of initiatives to foster entrepreneurship and the commercialisation of research results (through, for example, the Framework Programmes and Horizon 2020; European Commission 2013).

Thirdly, academia has responded to these two challenges by making commercialisation of their research output the third pillar of their mission (in addition to the two pillars of research and teaching; Etzkowitz 1998; Leydesdorff 2000; Rasmussen et al. 2006), by increasing their efforts in entrepreneurship education and training, and by developing the human capital for both students and researchers (Bienkowska and Klofsten 2012; Kuratko 2005; Etzkowitz and Klofsten 2005). Therefore, from both management and policy perspective, it is necessary to repeatedly study human capital, as this is a crucial factor in the increasing importance of the relation between individual capabilities and new venture outcomes.

The scope of the present study is limited to European product-oriented ASOs in their early development stage (post-start-up). It is important to recognise that ASOs are not a homogenous group (Birley 2002; Mustar et al. 2006): they exist for different reasons, emerge from different origins, and conduct different activities. A clear definition of the boundaries of the study, therefore, will contribute to the level of comparability of the results with other studies. In this sense, within the scope of this study an academic spinoff or ASO is defined as "a new legal entity (company) founded by one or more individuals from an (academic) parent organisation to exploit some kind of knowledge gained in the (academic) parent organisation and transferred to the new company" (De Cleyn and Braet 2009, p. 327). As this definition is still rather broad and covers new ventures deeply rooted in academic research as well as new ventures established by (highly) educated people based on knowledge gained through education or lectures at 
academic institutions, the scope of this study is further limited to those ASOs directly emerging out of academic research efforts.

Given the longer use of ASOs as technology transfer mechanism, it is not surprising that the majority of the studies on ASOs focus on the North-American situation (Degroof and Roberts 2003; Clarysse et al. 2005; Rothaermel et al. 2007; Yusof and Jain 2010). In order to increase the validity of the research stream (Rothaermel et al. 2007) and grasp the influence of intercultural differences through cross-country studies (Yusof and Jain 2010), this study adopts a multi-country approach in Europe. Data have therefore been collected in nine European countries.

Technology-based ventures face higher risks than service-oriented ventures (De Coster and Butler 2005). The challenges imposed by the technology (or by product development trajectory) require additional sets of capabilities, knowledge, and resources (Zeithaml et al. 1985; de Brentani 1991). This study only includes productoriented ASOs, which require an active involvement in new technology and/or (physical) product development (including software). Purely service-oriented ASOs (e.g. consulting firms) are excluded, given the different development path and risk associated to a product versus service-oriented venture. Product-oriented ventures are typically more capital intensive, have a more complex product development process with more inherent risks, have a longer time-to-market, require a different supply chain and have different scalability-aspect when compared to service-oriented ventures (Griffin 1997; Braet and Verhaert 2007).

A third boundary for the sample is the choice to study the early development process of ASOs. New ventures, especially in their earliest years, live through highly turbulent development periods (Davidsson and Klofsten 2003). For product-oriented ventures, the risks associated with the early development are even higher, since they face novelty in many dimensions (De Coster and Butler 2005). In this regard, product-oriented ASOs face three concurrent risks: a market risk (i.e. if the market will adopt the product or technology), a technological risk (i.e. if the technology will be able to be developed to a market-ready solution), and a risk originating from their non-commercial background (i.e. if the entrepreneurs will be able to adapt from an academic, non-businessoriented environment to a commercial business environment; De Coster and Butler 2005; Lerner 2005). Furthermore, the strategic choices made in the earliest stages have a greater impact on future development (this is idea of path dependency; see Degroof and Roberts 2003). Additionally, given the absence of a prior track record (Bathelt et al. 2010), the characteristics of key persons (in terms of human capital) to be foregrounded in the early development of new ventures, as these offer a source of credibility and legitimacy (Reagans and Zuckerman 2001; Shrader and Siegel 2007).

Early development, then, refers to the phases after the (legal) foundation of the new venture (i.e. post start-up; De Cleyn and Braet 2010), in which the (further) development of the first generation technology and product takes place (De Cleyn 2011). In line with the boundaries of the early development used in other studies, the early development in this study refers to the first 10 years after the legal foundation of the ASO (Bamberger et al. 1989; Chamanski and Waagø 2001; Song et al. 2008). Furthermore, this 10 year period additionally counters the effect of varying environmental and economic conditions (Terpstra and Olson 1993), as both periods of economic downturn and peaks of the business cycle are included in the time-frame of this study (1999-2009). 
This scope of this study is not limited to successful (surviving) ASOs, as this approach attempts to avoid the survivor bias common to many studies on new ventures (Davidsson et al. 2001). Although organisational failure is a common event, the subject has been under-researched (Blackburn and Kovalainen 2009) and is to some extent - at least in Europe - 'unmentionable' (Wilkinson and Mellahi 2005). The term failure in this study refers to its most basic definition: namely, bankruptcy. It is our belief that valuable lessons can be learnt from failure cases: this study therefore incorporates the lessons of 17 failed ASOs (in a total sample of 185 ASOs). The ASOs that survived at least up to the point of the interview are considered to be successes in the context of this study.

Even though the share of failed venture in the total sample seems small (17 out of 185 or $9.2 \%$ ), this is in line with the typical failure rate as suggested by a number of prior studies on ASOs. Despite the combination of the aforementioned technological and commercial risk on one hand and their emergence out of a non-commercial environment on the other, ASOs surprisingly tend to face lower failure rates. In a large-scale study on NTBFs in the Göteborg region (Sweden), Dahlstrand (1997) found that of the 240 ASOs originating from Chalmers University between 1960 and 1993, $87 \%$ were still alive in 1993 and the other $13 \%$ had been terminated. Another large-scale study reported that of the 2,578 ASOs founded between 1980 and 1998 in the U.S., $70 \%$ were still in operation in the latter year (Di Gregorio and Shane 2003). In two smaller samples, other scholars have found ASO failure rates of $10.7 \%$ over 10 years (sample of 26 Welch ASOs in the period 1990-1999) (Brooksbank and Thomas 2001) and 27.3\% over 12 years (sample of 22 Canadian and U.S. ASOs in the period 1989-2001) (Gurdon and Samsom 2010). Lynskey (2008) confirmed the low ASO failure rate of about $10 \%$ among ten U.K. universities, compared to the much higher rate of 60 to $70 \%$ for other high-tech firms (timeframe: 1998-2002, sample of 173 U.K. ASOs). In a sample of 3,115 European ASOs established between 1985 and 2008, an independent survival rate of $86 \%$ was found, while $4 \%$ continued in a dependent setting (merger or acquisition) and $10 \%$ ceased operations (liquidation or failure) (De Cleyn et al. 2010).

This low failure rate might be explained by the fact that other NTBFs are better equipped to exploit and market their own inventions, while ASOs develop new technologies that are subsequently exploited by other companies (Dahlstrand 1997). As a consequence, ASOs might be able to survive as independent, small and highly innovative ventures with a low failure rate (Dahlstrand 1997). Alternatively, Nerkar and Shane (2003) put forward that firms exploiting more radical technologies and broad patent scopes have higher survival chances. ASOs often fulfil both criteria, especially product-oriented ASOs (who are the focus of this study). Furthermore, some ASOs might survive in an artificial way using subsidies. Overall, ASOs seem to face relatively high survival rates.

\section{Research questions}

In an attempt to unravel the impact of different types of human capital endowments on ASO survival, this study addresses three research questions. These are discussed below.

\section{Research questions one and two}

This study builds upon prior scholarly work on human capital in technology-based ventures and investigates the importance of complementary teams in terms of prior 
functional background and prior education of the founders, managers and directors. Complementary teams have been shown to achieve greater likelihood of survival (Shane and Stuart 2002; Aspelund et al. 2005; Knockaert et al. 2011). However, in academic environments new ventures are, often established by teams who have predominantly technological or scientific backgrounds (Mosey and Wright 2007; Franklin et al. 2001). Building on this prior evidence, the first two research questions investigate if the positive impact of complementarity (functional and educational) teams on new venture development remains present for product-oriented ASOs:

RQ 1: How important is complementarity of team composition in terms of prior functional background for survival in the early development of academic spin-offs?

RQ 2: How important is complementarity of team composition in terms of prior education for survival in the early development of academic spin-offs?

\section{Research question three}

The third research question differentiates between different types of prior entrepreneurial experience. The impact of prior entrepreneurship experience on new venture success has been researched frequently (e.g. see Honig 1998; Davidsson and Honig 2003; Delmar and Shane 2006). Thus far, these studies have been inconclusive on the direction of the effects (Delmar and Shane 2006; Unger et al. 2011). Currently, the majority of scholarly studies on prior entrepreneurial experience take for granted a uniform impact on any type of entrepreneurial experience. Having taken into account the example of serial entrepreneurs (in terms of entrepreneurial euphoria and diminishing positive effect of prior experience), we assume a potentially different effect that depends on the type of prior entrepreneurial experience. In the context of productoriented ASOs, the type of new venture the founders and/or managers had previously founded and the outcome of this venture (success, bankruptcy, deliberate cessation, merger, acquisition) may be relevant. As such, the third research question not only investigates the overall importance of this prior experience, but also the underlying differences according to the nature of these experiences:

RQ 3: Are different types of prior entrepreneurial experiences in the early development of academic spin-offs correlated with its survival probability?

With respect to these research questions, the aim is to analyse whether there is a variation in the correlation between the human capital composition of the key persons and the success of academic spin-offs. By studying a European data set, the effect of initial human capital endowments in the early development of ASOs will be discussed and compared to prior literature on the subject.

In this regard, the contribution of this study to both human capital and academic spin-off literature is expected to be threefold. Firstly, at a theoretical level, this study adds to current understanding of the effects of prior entrepreneurial experience by differentiating between various types. We contribute to the theoretical stream on human capital endowments. Secondly, this study contributes to ASO practice by further disentangling the relationships between human capital characteristics and subsequent new venture survival. The results will be helpful in building entrepreneurial teams in academic environments. Finally, this study should confirm that entrepreneurial teams 
should change over time to better respond to changing challenges over the development of new ventures (Colombo and Grilli 2005; Mosey and Wright 2007). We contribute to the understanding of team evolution by measuring the effects at various points in the development of product-oriented ASOs.

\section{Research methodology}

\section{Data collection}

Data were collected using a two steps procedure, and by adopting a mixed-method approach. Firstly, 17 exploratory case studies were conducted using personal interviews with one of the active founders (mostly the CEO or CSO/CTO) of Belgian ASOs (random sampling). These interviews (1-1.5 h duration) were guided by a semi-structured questionnaire, which aimed at gaining insights into the relevant key persons' aspects during the early development stage of ASOs. The semi-structured approach allowed a rich set of both qualitative and quantitative data to be collected (Wengraf 2001). The questionnaire was further developed based on the outcome of the case studies the new insights that had been gained through eight expert interviews (1-3.5 h duration). These experts covered most stakeholders involved in the ASO process (entrepreneurs, TTO managers, incubator managers, financiers, consultants, and professors).

The outcomes of these exploratory, more qualitative case studies and expert interviews have been used as input to develop the more quantitative questionnaire for a larger data collection effort. The rich input from the qualitative phase has enabled us to develop a strong, more quantitative questionnaire grounded in practice. After a pre-test with ten early stage, product-oriented ASOs, these efforts together led to the development of a final questionnaire, which only contained closed-end questions on early ASO and team development.

The second step concerned the actual data collection. Data were collected on 185 ASOs in nine countries using personal interviews (about $1 \mathrm{~h}$ in duration) with the CEO or active founder (effective response rate of almost $93 \%$ ). The ASOs were selected using a combination of probabilistic (random) sampling and purposive (snowball) sampling, to ensure that multiple European countries are addressed. The former helps in achieving external validity, while the latter allows achieving higher response rates and increasing the usefulness of the selected cases (Goodman 1961; Welch 1975; Tashakkori and Teddlie 2003). However, all 185 ASOs interviewed were part of a database collected in an earlier research effort, which contains over 8,000 ASOs in Europe (see De Cleyn et al. 2010). Within this database, a number of regions and academic institutions have been chosen (in order to cover a variety of regions and cultures). Interviews were conducted in Belgium, Denmark, Germany, Italy, Norway, Spain, Sweden, the Netherlands, and the United Kingdom. Through referrals of local contacts (mostly TTO managers from the academic institutions in these regions), i.e. snowball sampling, and some randomly sampled ASOs, the final sample was constructed.

For each of the founders, managers and directors, we collected general data (gender, age, and full or part-time commitment), data on (type of) prior functional experience, data on (level and type of) prior education and data on the nature of prior entrepreneurial experience. With regard to performance variables, data have been collected on 
success versus failure (dichotomous variable) and yearly data on EBIT, total assets and turnover. Finally, data on employment (FTE or full-time equivalents) was collected, in order to effectively correct the data for ASO size.

After the interviews, the data was triangulated using other data sources: including the ASO's website, the financial database Amadeus (edited by Bureau Van Dijck; this also contains information on TMT and BoD members), the professional network site LinkedIn for personal profiles, and internet searches (mainly using Google). This procedure avoided the risk of hindsight bias and the risk associated with self-reported data (Rocco et al. 2003; Davidsson 2005).

In order to obtain a sample that was representative of the overall population of early stage product-oriented ASOs, the sample included ASOs that were still active $(n=151)$, had failed $(n=17)$, had been acquired by $(n=11)$ or merged with $(n=2)$ other firms, or had realised an initial public offering (IPO; $n=4)$. The sample focused on early stage ASOs (the age range was limited to 11 years or less) and covered a variety of industry sectors, with a strong representation of electronics, ICT, biotechnology, and pharmaceuticals. All ASOs in our sample were product-oriented ventures.

\section{Data analysis}

Two types of techniques were used for the data analysis, depending on the type of data. To distinguish the two groups of ASOs (a dependent variable), the dichotomous success versus failure variable was used. In case of ordinal variables (e.g. level or type of education or type of prior functional experience) differences between the two groups were tested using logistic regression, which provides information on the direction and significance of the effect of explanatory (independent) variables on the dependent variable (Kuhnert et al. 2000; Hastie et al. 2001; Keller 2005) and the likelihood of correctly classifying the presence (or absence) of an event (Tansey et al. 1996). One of the main advantages of logistic regression is that it does not necessarily assume a linear relationship between the independent and dependent variables (Lo 1986; Youn and Gu 2010).

In the case of interval dependent variables (e.g. EBIT/FTE, total assets/FTE, and turnover/FTE) the second type of analyses concerned $t$-tests (Keller 2005). In this case, the two populations were the independent groups of failed and surviving ASOs. The Levene's test, with the correction for unequal sample sizes, was used to analyse the homogeneity of variances across the populations (Levene 1960; Brown and Forsythe 1974). The relationship of these variables with the heterogeneity of management team and board of directors (in terms of prior functional experience and educational degree) was tested on years 2, 4, 6, and 8 after the ASO's foundation (year 1 being the first year after its foundation).

A major limitation of this study concerns the operationalising of the dependent variable (binary success-failure). One could argue that, especially in the early development of ASOs, a certain share of ventures did not really face the market test, as their first core product was still under development. As long as these ASOs did not realise any turnover, it might be questionable to categorise them as successes (they might be 'false positives'). In this sample, 59 ASOs did not realise any product sales at the time of the interview, of which ten were failures. Even though the number of failures in this subsample was small, two robustness checks were performed. Firstly, the 49 surviving ASOs without product sales were excluded from the sample. In this new dataset, all the results obtained were 
confirmed. One additional result was obtained: ongoing founder involvement turned out to have a significant positive impact on ASO success; although not if this involvement occurred as CEO. Secondly, by means of an experiment, ten randomly selected surviving ASOs without core product sales were categorised as failures instead of successes. Again, all the prior results were confirmed. Therefore, the results obtained in this sample of 185 European early stage ASOs can be considered to be robust.

\section{Results}

The impact of human capital characteristics on ASO success was analysed on three levels: top management team, board of directors, and founders.

\section{Top management team}

The results of the $t$-test in Table 1 suggest that larger TMTs are better equipped to face the challenges associated with new ASO development. On average, failed ASOs seem to have smaller TMTs (an average of 2.0 TMT members compared to 2.6 for the surviving ASOs). This finding is in line with prior studies on the subject, which have suggested that a large TMT will provide several benefits for a venture: including a larger pool of knowledge, experience and expertise, and a greater likelihood of attracting external funding (e.g., see meta-analysis: Song et al. 2008; Unger et al. 2011).

Further results in Table 1 suggest a significant and positive impact from TMT members with prior experience in financial functions (significant at $\alpha=5 \%$ ). The relationship between ASO success and prior entrepreneurial experience of TMT members is, however, less clear (Florin et al. 2003; Baum and Silverman 2004; Unger et al. 2011). Delmar and Shane (2006) have already pointed to the complex and indirect relationship between prior entrepreneurial experience and new venture success. In our study, the presence of top managers who have prior entrepreneurial experience (whether in any type of start-up or in high-tech start-ups) had a significant positive influence on ASO survival odds (significant at $\alpha=1 \%$ ). However, this positive effect disappeared in case of serial entrepreneurs. In the current sample, 54 ASOs (out of the total sample of 185) had managers in the team with prior entrepreneurial experience (in at least one other start-up), while 33 had managers on board with multiple other prior start-ups. This is in line with prior findings, which indicated that serial entrepreneurs tend to search less for relevant information and become subject to entrepreneurial euphoria and overconfidence (Cooper et al. 1995).

None of the other variables (TMT age and gender diversity, other types of educational background, or types of prior work, management or industry experience) seem to have exerted a significant impact on ASO success.

Heterogeneous teams have been said to better be equipped to recognise signals of changes in a venture's environment, leading to a higher probability of success (Shane and Stuart 2002; Aspelund et al. 2005; Knockaert et al. 2011). According to human capital theory, this heterogeneity can - amongst other sources - stem from education (see e.g. Cooper et al. 1994; Sapienza and Grimm 1997; Watson et al. 2003; Amason et al. 2006) and prior work experience (see e.g. Brüderl et al. 1992; Zacharakis and Meyer 2000; Watson et al. 2003; Mosey and Wright 2007). 


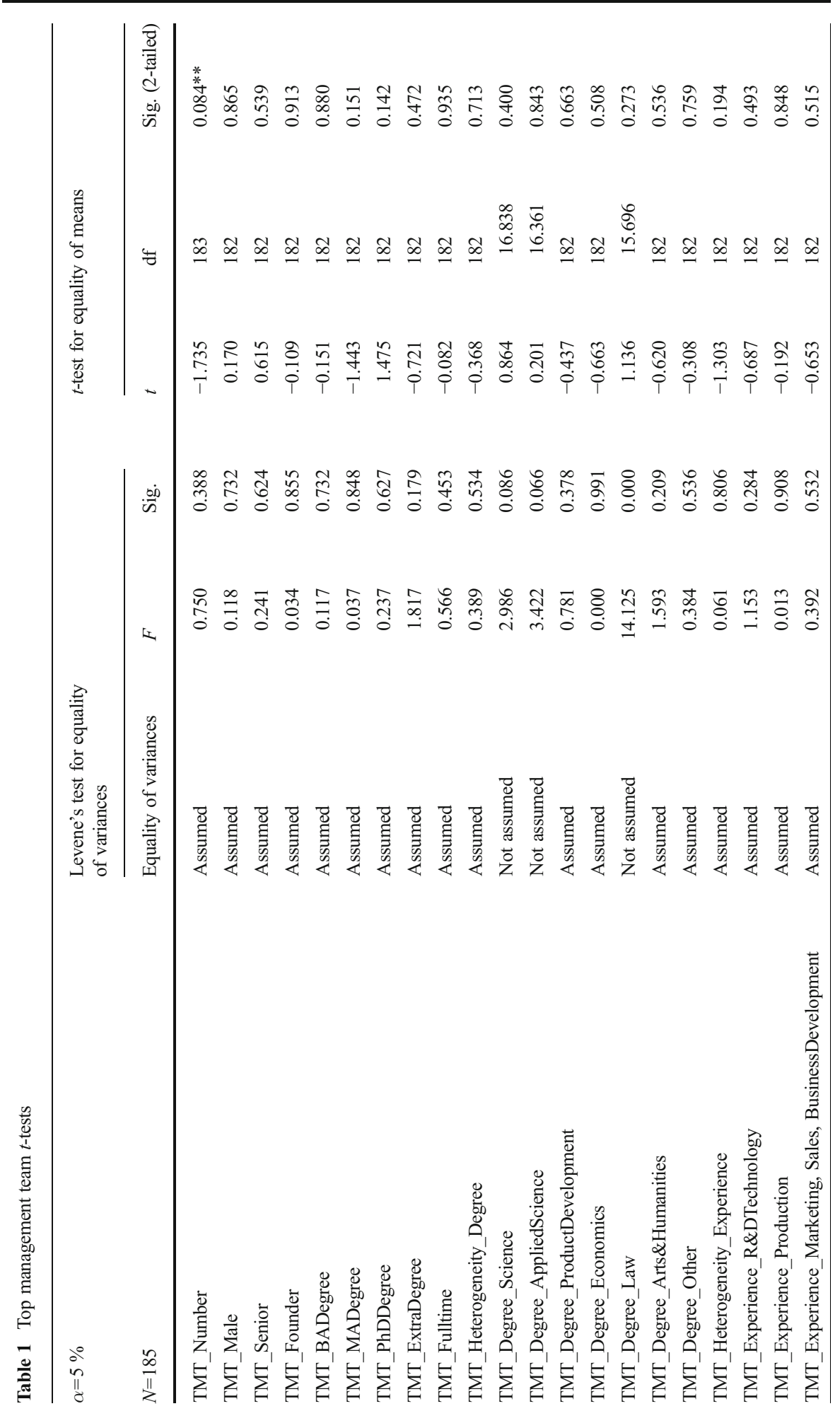




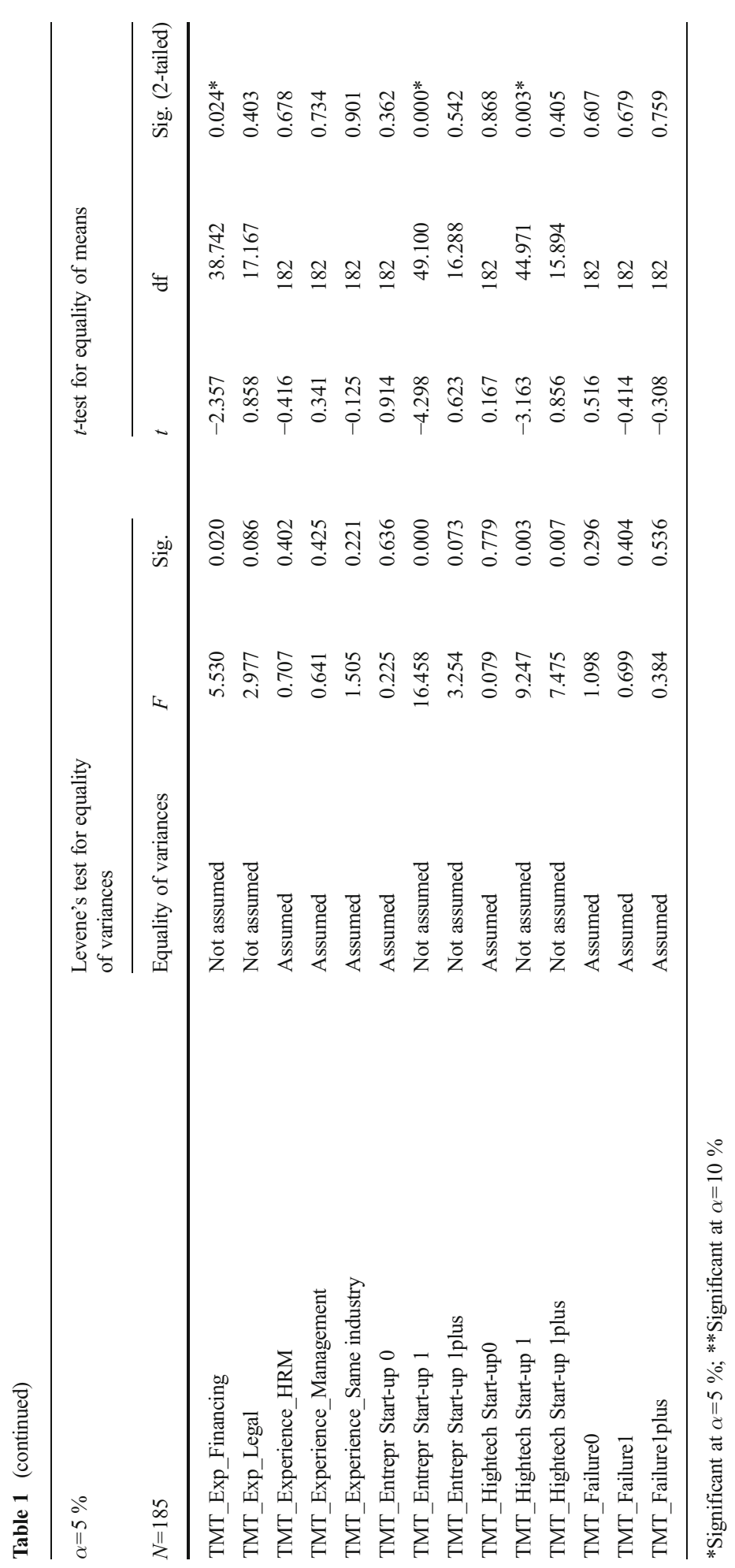


The results in Table 2 suggest an additional effect between TMT human capital on one hand and ASO success on the other. These heterogeneous TMTs in terms of prior education and work experience have a significant positive impact on ASO success (measured by EBIT per full-time equivalent [FTE], total assets per FTE, and turnover per FTE). The effect was, however, strong in the first years after ASO foundation (often significant at $\alpha=1 \%$ for year 2), but disappeared over time. The heterogeneity of a TMT is, thus, an important aspect in the earliest development of ASOs; while over time-due to learning curves-its importance fades away (as other TMT member become better acquainted with the requirements of other tasks and responsibilities). Although

Table 2 Relationship TMT heterogeneity-performance

\begin{tabular}{|c|c|c|c|c|c|}
\hline \multicolumn{6}{|l|}{$\alpha=5 \%$} \\
\hline Dep. var. & Indep. var. & Number observ. & Stand. coeff. & Adj. $R^{2}$ & Sig. \\
\hline \multicolumn{6}{|l|}{ EBIT/FTE } \\
\hline \multirow[t]{2}{*}{ EBIT/FTE Y2 } & TMT_Hetero_Experience & 123 & -0.310 & 0.089 & $0.000 *$ \\
\hline & TMT_Hetero_Degree & 123 & -0.404 & 0.156 & $0.000^{*}$ \\
\hline \multirow[t]{2}{*}{ EBIT/FTE Y4 } & TMT_Hetero_Experience & 98 & -0.288 & 0.073 & $0.004 *$ \\
\hline & TMT_Hetero_Degree & 98 & -0.255 & 0.056 & $0.011^{*}$ \\
\hline \multirow[t]{2}{*}{ EBIT/FTE Y6 } & TMT_Hetero_Experience & 51 & -0.199 & 0.020 & 0.162 \\
\hline & TMT_Hetero_Degree & 51 & -0.134 & -0.002 & 0.349 \\
\hline \multirow[t]{2}{*}{ EBIT/FTE Y8 } & TMT_Hetero_Experience & 32 & 0.011 & -0.033 & 0.952 \\
\hline & TMT_Hetero_Degree & 32 & -0.258 & 0.036 & 0.153 \\
\hline \multicolumn{6}{|l|}{ Total assets/FTE } \\
\hline \multirow[t]{2}{*}{ Total assets/FTE Y2 } & TMT_Hetero_Experience & 122 & 0.152 & 0.015 & $0.094 * *$ \\
\hline & TMT_Hetero_Degree & 122 & 0.216 & 0.039 & $0.017^{*}$ \\
\hline \multirow[t]{2}{*}{ Total assets/FTE Y4 } & TMT_Hetero_Experience & 99 & 0.082 & -0.003 & 0.417 \\
\hline & TMT_Hetero_Degree & 99 & 0.119 & 0.004 & 0.240 \\
\hline \multirow[t]{2}{*}{ Total assets/FTE Y6 } & TMT_Hetero_Experience & 52 & 0.212 & 0.026 & 0.131 \\
\hline & TMT_Hetero_Degree & 52 & -0.033 & -0.019 & 0.818 \\
\hline \multirow[t]{2}{*}{ Total assets/FTE Y8 } & TMT_Hetero_Experience & 32 & 0.309 & 0.066 & $0.085^{* *}$ \\
\hline & TMT_Hetero_Degree & 32 & -0.016 & -0.033 & 0.932 \\
\hline \multicolumn{6}{|l|}{ Turnover/FTE } \\
\hline \multirow[t]{2}{*}{ Turnover/FTE Y2 } & TMT_Hetero_Experience & 123 & 0.154 & 0.016 & $0.089^{* *}$ \\
\hline & TMT_Hetero_Degree & 123 & -0.111 & 0.004 & 0.221 \\
\hline \multirow[t]{2}{*}{ Turnover/FTE Y4 } & TMT_Hetero_Experience & 99 & 0.140 & 0.010 & 0.166 \\
\hline & TMT_Hetero_Degree & 99 & 0.048 & -0.008 & 0.639 \\
\hline \multirow[t]{2}{*}{ Turnover/FTE Y6 } & TMT_Hetero_Experience & 52 & 0.043 & -0.018 & 0.763 \\
\hline & TMT_Hetero_Degree & 52 & -0.116 & -0.006 & 0.412 \\
\hline \multirow[t]{2}{*}{ Turnover/FTE Y8 } & TMT_Hetero_Experience & 32 & 0.070 & -0.028 & 0.702 \\
\hline & TMT_Hetero_Degree & 32 & -0.242 & 0.027 & 0.181 \\
\hline
\end{tabular}

*Significant at $\alpha=5 \%$; ** Significant at $\alpha=10 \%$ 
heterogeneous TMTs have been attributed better survival chances by earlier studies (Shane and Stuart 2002; Aspelund et al. 2005; Knockaert et al. 2011), especially in ASO TMTs which are often dominated by technological profiles (Franklin et al. 2001; Ensley and Hmieleski 2005), this effect phasing out over time is new.

\section{Board of directors}

The BoD has been considered an important source of human capital, and as complementary to that of the TMT. Directors add additional insights through their expertise and increase legitimacy towards external entities (Bjørnåli and Gulbrandsen 2010).

In our sample, 47 ASOs (25 \%) did not install a BoD. However, merely having a BoD or not does not seem to affect ASO survival probability. Table 3 provides the results of the $t$-test, which did not find any significant effect from BoD size on ASO survival chances. The results indicate, however, a significant impact from BoD diversity in terms of age and gender on ASO success. The BoDs with a higher share of male directors faced a significantly lower failure risk $(\alpha=10 \%)$. This result might be mitigated by the relative low number of BoDs containing female directors (34 of out 185 or $18 \%$ ). These results are, however, in line with prior findings of van der Walt and Ingley (2003). Furthermore, prior research has suggested that more diverse BoDs (in terms of seniority) face lower failure risks (Siciliano 1996; van der Walt and Ingley 2003). Directors of different ages (and therefore with diverse experience levels) might have different worldviews and ideas, thereby increasing their creativity and problem-solving skills. The results indicate that BoDs with a lower share of senior directors (i.e. with a more diverse BoD in terms of seniority) enjoy higher survival chances (statistically significant at $\alpha=5 \%$ ).

In line with the results found for the TMT, heterogeneity of the BoD in terms of education and prior work experience plays a significant positive but diminishing effect (see Table 4). This result confirms prior findings on the importance of BoD heterogeneity (Erhardt et al. 2003; Clarysse et al. 2007; Bjørnåli and Gulbrandsen 2010) and adds new insights on its effects phasing out over time over the development of ASOs.

Although heterogeneity adds significantly to ASO survival probability, one individual discipline stands out. If the BoD contains directors with legal expertise (education and/or prior work experience), the ASO will enjoy significantly higher odds of achieving success (significant $\alpha=1 \%$; see Table 3). In our sample, 65 ASOs (out of 138 ASOs with a BoD) had directors with a law degree, and 62 of these had directors with experience in legal functions.

\section{Founders}

Surprisingly, none of the founder characteristics (education, work experience, heterogeneity, participation, or prior entrepreneurial experience) had a significant effect on ASO success. This result might be attributed to the fact that only 23 ASOs in the sample $(12 \%)$ did not have any founders involved at the time of the interview. This finding contradicts prior research (even given the low occurrence of ASOs having no founders involved anymore in our sample), which placed emphasis on the importance of an ongoing involvement and relationship of the founders (Doutriaux 1987; Rothaermel and Thursby 2005; Gurdon and Samsom 2010). 


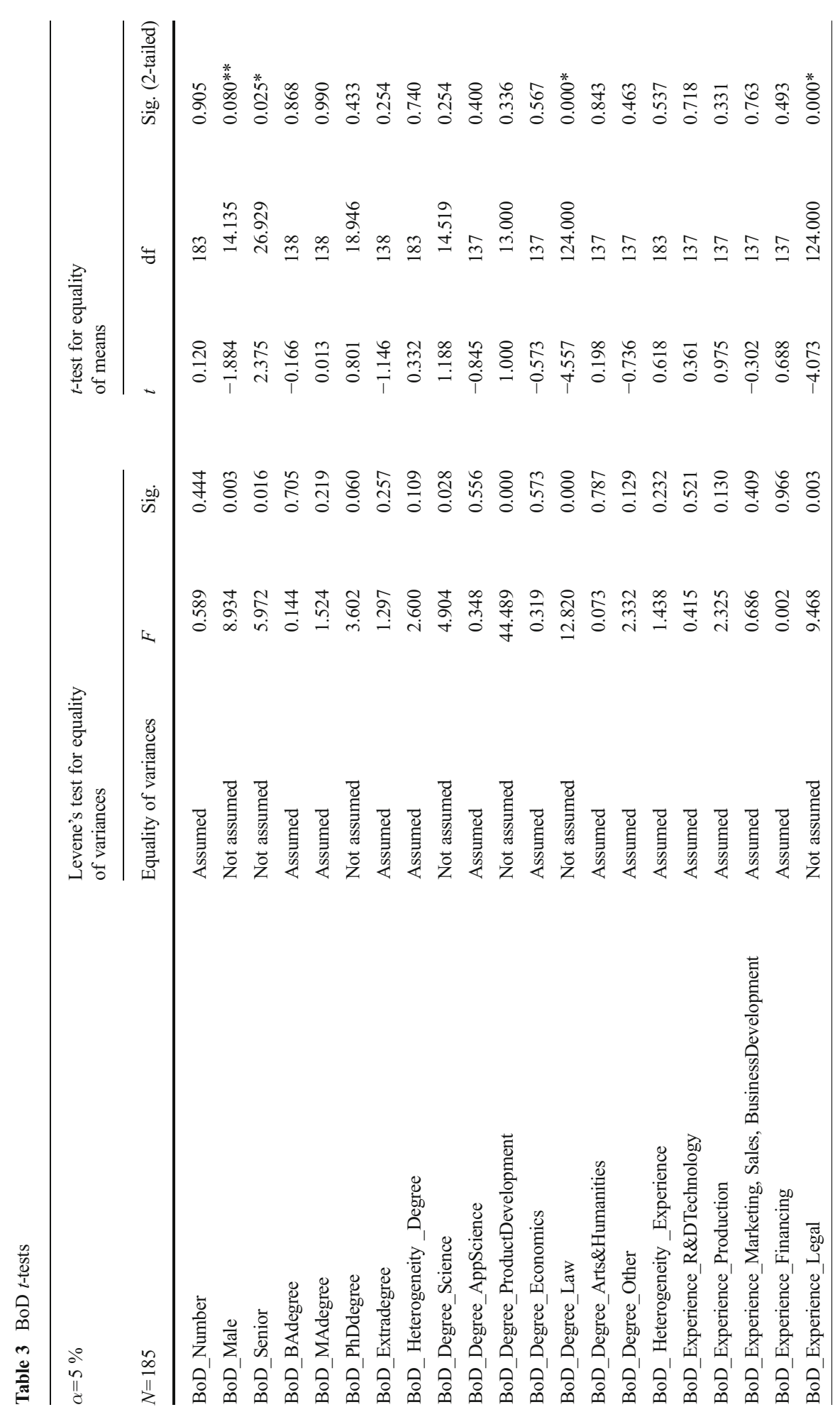




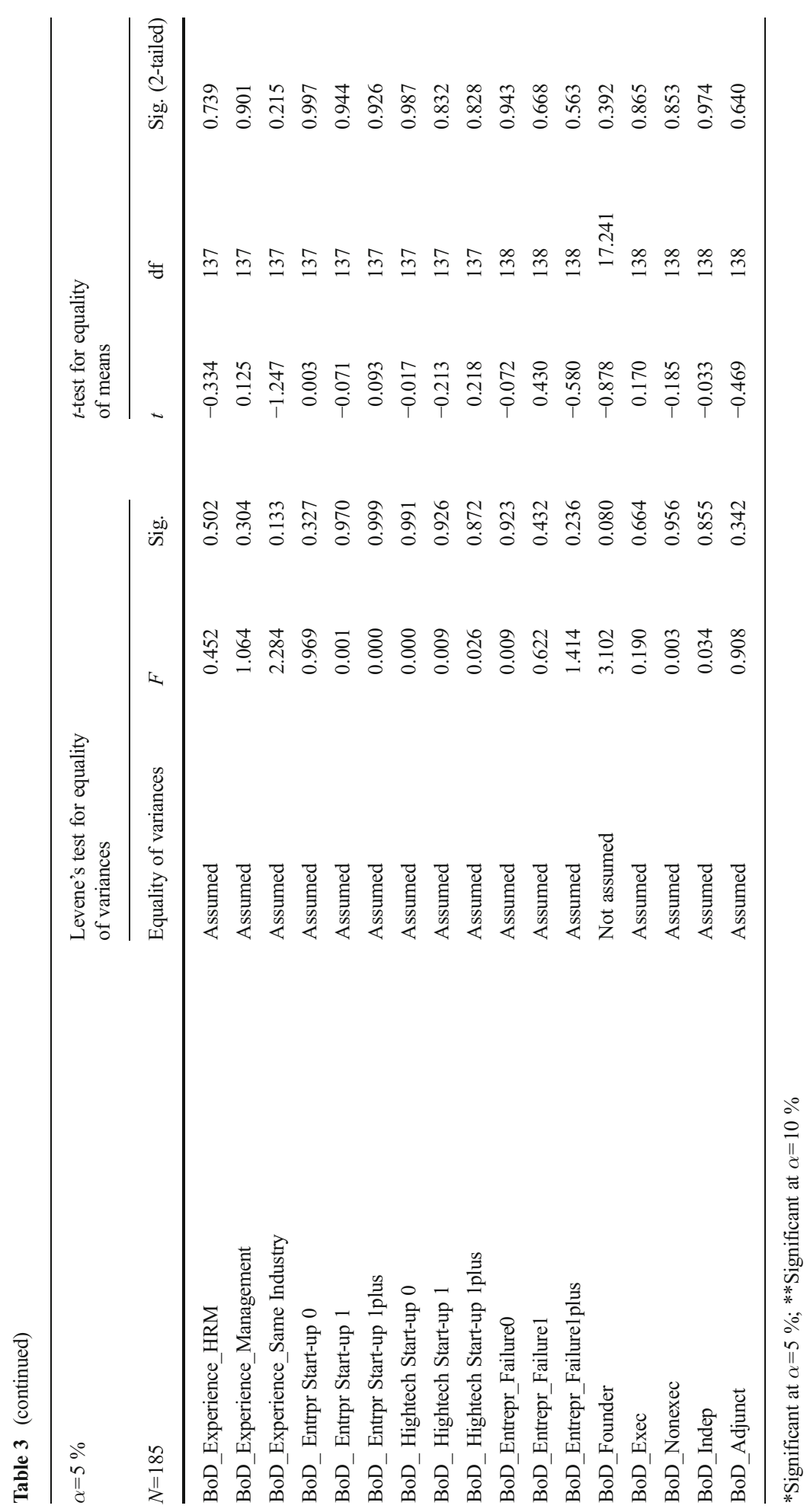


Table 4 Relationship BoD heterogeneity-performance

\begin{tabular}{|c|c|c|c|c|c|}
\hline Dep. var. & Indep. var. & Number observ. & Stand. coeff. & Adj. $\mathrm{R}^{2}$ & Sig. \\
\hline \multicolumn{6}{|l|}{ EBIT/FTE } \\
\hline \multirow[t]{2}{*}{ EBIT/FTE Y2 } & BoD_Hetero_Experience & 124 & -0.322 & 0.097 & $0.000 *$ \\
\hline & BoD_Hetero_Degree & 124 & -0.392 & 0.147 & $0.000^{*}$ \\
\hline \multirow[t]{2}{*}{ EBIT/FTE Y4 } & BoD_Hetero_Experience & 99 & -0.293 & 0.076 & $0.003^{*}$ \\
\hline & BoD_Hetero_Degree & 99 & -0.271 & 0.064 & $0.007^{*}$ \\
\hline \multirow[t]{2}{*}{ EBIT/FTE Y6 } & BoD_Hetero_Experience & 52 & -0.107 & -0.008 & 0.452 \\
\hline & BoD_Hetero_Degree & 52 & -0.020 & -0.020 & 0.890 \\
\hline \multirow[t]{2}{*}{ EBIT/FTE Y8 } & BoD_Hetero_Experience & 32 & 0.164 & -0.005 & 0.368 \\
\hline & BoD_Hetero_Degree & 32 & -0.043 & -0.031 & 0.815 \\
\hline \multicolumn{6}{|l|}{ Total assets/FTE } \\
\hline \multirow[t]{2}{*}{ Total assets/FTE Y2 } & BoD_Hetero_Experience & 123 & 0.182 & 0.025 & $0.044 *$ \\
\hline & BoD_Hetero_Degree & 123 & 0.213 & 0.038 & $0.018^{*}$ \\
\hline \multirow[t]{2}{*}{ Total assets/FTE Y4 } & BoD_Hetero_Experience & 100 & 0.210 & 0.034 & $0.036^{*}$ \\
\hline & BoD_Hetero_Degree & 100 & 0.135 & 0.008 & 0.179 \\
\hline \multirow[t]{2}{*}{ Total assets/FTE Y6 } & BoD_Hetero_Experience & 53 & 0.294 & 0.068 & $0.033^{*}$ \\
\hline & BoD_Hetero_Degree & 53 & 0.215 & 0.027 & 0.122 \\
\hline \multirow[t]{2}{*}{ Total assets/FTE Y8 } & BoD_Hetero_Experience & 32 & 0.304 & 0.062 & $0.091^{* *}$ \\
\hline & BoD_Hetero_Degree & 32 & 0.287 & 0.052 & 0.112 \\
\hline \multicolumn{6}{|l|}{ Turnover/FTE } \\
\hline \multirow[t]{2}{*}{ Turnover/FTE Y2 } & BoD_Hetero_Experience & 124 & 0.127 & 0.008 & 0.160 \\
\hline & BoD_Hetero_Degree & 124 & -0.024 & -0.008 & 0.793 \\
\hline \multirow[t]{2}{*}{ Turnover/FTE Y4 } & BoD_Hetero_Experience & 100 & 0.081 & -0.004 & 0.421 \\
\hline & BoD_Hetero_Degree & 100 & 0.100 & 0.000 & 0.324 \\
\hline \multirow[t]{2}{*}{ Turnover/FTE Y6 } & BoD_Hetero_Experience & 53 & 0.199 & 0.021 & 0.153 \\
\hline & BoD_Hetero_Degree & 53 & 0.193 & 0.018 & 0.167 \\
\hline \multirow[t]{2}{*}{ Turnover/FTE Y8 } & BoD_Hetero_Experience & 32 & 0.167 & -0.004 & 0.360 \\
\hline & BoD_Hetero_Degree & 32 & 0.028 & -0.032 & 0.877 \\
\hline
\end{tabular}

*Significant at $\alpha=5 \%$; ** Significant at $\alpha=10 \%$

\section{Discussion and conclusions}

\section{Discussion}

In a new venture's early development, the characteristics of key persons (in the form of human capital) play a crucial role by providing a source of legitimisation and credibility. This study has attempted to unravel the significance and direction of the effect of human capital endowments on the success of early stage product-oriented ASOs. Within the framework of this study, two main forms of human capital have been investigated: complementarity in terms of functional background and education on one hand, and prior entrepreneurial experience on the other. 
The results have pointed to the important role of heterogeneity, both at TMT and BoD levels. Given the complexity of the tasks in early stage ASOs (being the simultaneous development of a new technology/product, a new organisation, and a market for the product), the required expertise is unlikely to be found in a single person (Franklin et al. 2001). In the complex high-tech environments in which ASOs often operate, the importance of heterogeneity is even more apparent, especially given the domination of people with a technological background in most ASOs (Mosey and Wright 2007). In this sense, the result support our first two research questions, that related to the importance of team heterogeneity (in terms of functional background and education) on ASO survival.

A second important finding relates to the significant positive effect of legal expertise in the BoD. Given the role of BoDs in a venture's strategic decision making and control of TMT operations, this important effect is in a certain way natural. Furthermore, the increasing interest of contracts and — certainly in a high-tech environment - intellectual property rights call for more expertise in this domain.

The third important finding relates to the third research question that explored the relationship between different types of prior entrepreneurial experience and ASO survival. At TMT level, this relationship turned out to be most important. This is not surprising, since the TMT is the most operational part of the overall ASO team and as such has most direct impact on ASO success. Contrary to prior studies, our results did not confirm the strong and positive impact of serial entrepreneurs on ASO survival. In fact, entrepreneurs engaged in their second venture have been demonstrated to be still eager to make it a true success, while in subsequent new ventures the (negative) effect over entrepreneurial euphoria and overconfidence tend to over-compensate the positive effects of prior entrepreneurial experience.

These results contribute to our current understanding of human capital in ASOs in many regards. From a theoretical viewpoint, the study has shown that prior entrepreneurial experience is not a homogeneous concept. The effect of prior entrepreneurial experience on subsequent new venture success varies according to its nature. Furthermore, the effect is different for managers and directors. Further research could elaborate on this subject.

From a more practical perspective, this study has demonstrated a number of effects that further contribute to our understanding of entrepreneurial teams and their 'optimal' composition. On one hand, our results have pointed to several individual elements that could foster ASO survival and success, which have not appeared in scholarly research before (e.g. the strong and positive effect of legal expertise at $\mathrm{BoD}$ level or the different effect of prior entrepreneurial experience at TMT and BoD level). On the other hand, the need for entrepreneurial teams to change over time is not new (see Morgan and Salas 1993; Clarysse and Moray 2004; Vanaelst et al. 2006; Bjørnåli and Gulbrandsen 2010; Gurdon and Samsom 2010); however, the disappearing positive effect of heterogeneity over time is. These new insights can strengthen research on both human capital as well as ASOs.

Policy implications

The results obtained have important implications for entrepreneurial academics, ASO managers, and TTOs. These results indicate that more attention should be devoted to team composition and to the added value in terms of human capital of new team members. Heterogeneous teams are better equipped to face the multi-faceted challenges 
imposed by the early stage development of ASOs. Likewise, ASO might benefit from experienced entrepreneurs in their team. Both the results in this study and prior literature on entrepreneurial euphoria (see Literature review: human capital and ASOs), however, suggest some negative effects of serial entrepreneurs in new venture performance. For this team development process, various mechanisms have been developed to find a balance between technological expertise and entrepreneurial skills at TMT level and to compose a BoD that brings substantial added value and supports the TMT. In this regard, entrepreneurs-in-residence, independent directors, and/or advisory boards could be used to add human capital to an ASO team (see e.g. Rosenblatt and Thelen 1997; Deakins and Boussouara 2000; Clarysse and Moray 2004; Clarysse et al. 2007; Bjørnåli and Gulbrandsen 2010; George et al. 2010).

This study has pointed to the importance of team composition in early stage productoriented ASOs: both at TMT and BoD level. This confirms the call for more attention to the team development process, as put forward by Ensley and Hmieleski (2005). The main results concern the significant positive effect of TMT and BoD heterogeneity, which disappears over time, and the strong positive impact of directors with legal expertise.

Acknowledgments The authors gratefully acknowledge the financial support received from the Research Foundation Flanders (FWO Vlaanderen) on behalf of Sven H. De Cleyn, as $\mathrm{PhD}$ fellow, during the data collection and analysis period. Furthermore, the authors would like to express their gratitude towards all entrepreneurs that contributed to this research project. The first version of this paper was presented at the 2011 Babson College Entrepreneurship Research Conference and published in the 2011 edition of Frontiers of Entrepreneurship Research.

\section{References}

Amason, A. C., Shrader, R. C., \& Tompson, G. H. (2006). Newness and novelty: relating top management team composition to new venture performance. Journal of Business Venturing, 21(1), 125-148.

Aspelund, A., Berg-Utby, T., \& Skjevdal, R. (2005). Initial resources' influence on new venture survival: a longitudinal study of new technology-based firms. Technovation, 25(11), 1337-1347.

Bamberger, P., Bacharach, S., \& Dyer, L. (1989). Human resources management and organizational effectiveness: high technology entrepreneurial startup firms in Israel. Human Resource Management, 28(3), 349-366.

Barney, J. (1991). Firm resources and sustained competitive advantage. Journal of Management, 17(1), 99-120.

Bathelt, H., Kogler, D. F., \& Munro, A. K. (2010). A knowledge-based typology of university spin-offs in the context of regional economic development. Technovation, 30(9-10), 519-532.

Baum, J. A. C., \& Silverman, B. S. (2004). Picking winners or building them? Alliance, intellectual, and human capital as selection criteria in venture financing and performance of biotechnology startups. Journal of Business Venturing, 19(3), 411-436.

Bienkowska, D., \& Klofsten, M. (2012). Creating entrepreneurial networks: academic entrepreneurship, mobility and collaboration during $\mathrm{PhD}$ education. Higher Education, 64(2), 207-222.

Birley, S. (2002). Universities, academics, and spinout companies: lessons from imperial. International Journal of Entrepreneurship Education, 1(1), 133-154.

Bjørnåli, E. S., \& Gulbrandsen, M. (2010). Exploring board formation and evolution of board composition in academic spin-offs. Journal of Technology Transfer, 35(1), 92-112.

Blackburn, R., \& Kovalainen, A. (2009). Researching small firms and entrepreneurship: past, present and future. International Journal of Management Reviews, 11(2), 127-148.

Braet, J., \& Verhaert, P. (2007). The practice of new products and new business. Leuven: Acco.

Brooksbank, D., \& Thomas, B. (2001). An assessment of higher education spin-off enterprises in Wales. Industry \& Higher Education, 15(6), 415-420.

Brown, M. B., \& Forsythe, A. B. (1974). Robust tests for the equality of variances. Journal of the American Statistical Association, 69(346), 364-367. 
Brüderl, J., \& Schussler, R. (1990). Organizational mortality: the liabilities of newness and adolescence. Administrative Science Quarterly, 35(3), 530-547.

Brüderl, J., Preisendörfer, P., \& Ziegler, R. (1992). Survival chances of newly founded business organizations. American Sociological Review, 57(2), 227-242.

Carayannis, E. G., Rogers, E. M., Kurihara, K., \& Allbritton, M. M. (1998). High-technology spin-offs from government R\&D laboratories and research universities. Technovation, 18(1), 1-11.

Chamanski, A., \& Waagø, S. J. (2001). The organizational success of new, technology-based firms. Trondheim: Norwegian University of Science and Technology.

Clarysse, B., \& Moray, N. (2004). A process study of entrepreneurial team formation: the case study of a research-based spin-off. Journal of Business Venturing, 19(1), 55-79.

Clarysse, B., Wright, M., Lockett, A., Van de Velde, E., \& Vohora, A. (2005). Spinning out new ventures: a typology of incubation strategies from European research institutions. Journal of Business Venturing, 20(2), 183-216.

Clarysse, B., Knockaert, M., \& Lockett, A. (2007). Outside board members in high tech start-ups. Small Business Economics, 29(3), 243-259.

Coleman, J. S. (1988). Social capital in the creation of human capital. American Journal of Sociology, 94(Supplement), S95-S120.

Colombo, M. G., \& Grilli, L. (2005). Founders' human capital and the growth of new technology-based firms: a competence-based view. Research Policy, 34(6), 795-816.

Cooper, A. C., Folta, T. B., \& Woo, C. Y. (1995). Entrepreneurial information search. Journal of Business Venturing, 10(2), 107-120.

Cooper, A. C., Gimeno-Gascon, F. J., \& Woo, C. Y. (1994). Initial human and financial capital as predictors of new venture performance. Journal of Business Venturing, 9(5), 371-395.

Dahlstrand, A. L. (1997). Entrepreneurial spin-off enterprises in Goteborg, Sweden. European Planning Studies, 5(5), 659-673.

Davidsson, P. (2005). Method issues in the study of venture start-up processes. In A. Fayolle, P. Kyrö, \& J. M. Ulijn (Eds.), Entrepreneurship research in Europe: Outcomes and perspectives. Cheltenham: Edward Elgar Publishing.

Davidsson, P., \& Honig, B. (2003). The role of social and human capital among nascent entrepreneurs. Journal of Business Venturing, 18(3), 301-331.

Davidsson, P., \& Klofsten, M. (2003). The business platform: developing an instrument to gauge and to assist the development of young firms. Journal of Small Business Management, 41(1), 1-26.

Davidsson, P., Low, M., \& Wright, M. (2001). Editors'introduction: Low and MacMillan ten years on—achievements and future directions for entrepreneurship research. Entrepreneurship Theory \& Practice, 25(4), 5-16.

de Brentani, U. (1991). Success factors in developing new business services. European Journal of Marketing, 25(2), 33-59.

De Cleyn, S. H. (2011). The early development of academic spin-offs: A holistic study on the survival of 185 European product-oriented ventures using a resource-based perspective. Antwerp: University of Antwerp, Faculty of Applied Economics.

De Cleyn, S. H., \& Braet, J. (2009). Research valorisation through spin-off ventures: integration of existing concepts and typologies. World Review of Entrepreneurship, Management and Sustainable Development, 5(4), 325-352.

De Cleyn, S. H., \& Braet, J. (2010). The evolution of spin-off ventures: an integrated model. International Journal of Innovation and Technology Management, 7(1), 53-70.

De Cleyn, S. H., Tietz, R., Braet, J., \& Schefczyck, M. (2010). Status of academic entrepreneurship in Europe: 1985-2008. Puurs: Unibook.

De Coster, R., \& Butler, C. (2005). Assessment of proposals for new technology ventures in the UK: characteristics of university spin-off companies. Technovation, 25(5), 535-543.

Deakins, D., \& Boussouara, M. (2000). The role and impact of external (non-executive) directors and advisers in high technology small companies. In W. During, R. Oakey, \& M. Kipling (Eds.), New technology based firms at the turn of the century (pp. 11-34). Oxford: Elsevier Science.

Degroof, J.-J., \& Roberts, E. B. (2003). Spinning-off new ventures from academic institutions in areas with weak entrepreneurial infrastructure: Insights on the impact of spin-off processes on the growthorientation of ventures. Cambridge: MIT Sloan School of Management.

Delmar, F., \& Shane, S. (2004). Legitimating first: organizing activities and the survival of new ventures. Journal of Business Venturing, 19(3), 385-410.

Delmar, F., \& Shane, S. (2006). Does experience matter? The effect of founding team experience on the survival and sales of newly founded ventures. Strategic Organization, 4(3), 215-247.

Di Gregorio, D., \& Shane, S. (2003). Why do some universities generate more start-ups than others ? Research Policy, 32(2), 209-227. 
Doutriaux, J. (1987). Growth pattern of academic entrepreneurial firms. Journal of Business Venturing, 2(4), 285-297.

Drori, I., Honig, B., \& Scheaffer, Z. (2009). The life-cycle of an internet firm: scripts, legitimacy and identity. Entrepreneurship: Theory and Practice, 33(3), 715-738.

Ensley, M. D., \& Hmieleski, K. M. (2005). A comparative study of new venture top management team composition, dynamics and performance between university-based and independent start-ups. Research Policy, 34(7), 1091-1105.

Erhardt, N. L., Werbel, J. D., \& Shrader, C. B. (2003). Board of director diversity and firm financial performance. Corporate Governance, 11(2), 102-111.

Etzkowitz, H. (1998). The norms of entrepreneurial science: cognitive effects of the new university-industry linkages. Research Policy, 27(8), 823-833.

Etzkowitz, H., \& Klofsten, M. (2005). The innovating region: toward a theory of knowledge-based regional development. $R \& D$ Management, 35(3), 243-255.

European Commission (2013). Research \& innovation - horizon 2020. Online available at http://ec.europa.eu/ research/horizon2020. Last consulted on 25 January 2013.

Fichman, M., \& Levinthal, D. A. (1991). Honeymoons and the liability of adolescence: a new perspective on duration dependence in social and organizational relationships. Academy of Management Review, 16(2), 442-468.

Florin, J., Lubatkin, M., \& Schulze, W. (2003). A social capital model of high-growth ventures. Academy of Management Journal, 48(3), 374-384.

Franklin, S. J., Wright, M., \& Lockett, A. (2001). Academic and surrogate entrepreneurs in university spin-out companies. Journal of Technology Transfer, 26(1-2), 127-141.

George, M., Gordon, I., \& Hamilton, E. (2010). What is (the point of) an entrepreneur in residence? The Lancaster University experience, with some worldwide comparisons. Industry \& Higher Education, 24(6), 495-503.

Gimeno, J., Folta, T. B., Cooper, A. C., \& Woo, C. Y. (1997). Survival of the fittest? Entrepreneurial human capital and the persistence of underperforming firms. Administrative Science Quarterly, 42(4), 750-783.

Goldfarb, B., \& Henrekson, M. (2003). Bottom-up versus top-down policies towards the commercialization of university intellectual property. Research Policy, 32(4), 639-658.

Goodman, L. A. (1961). Snowball sampling. The Annals of Mathematical Statistics, 32(1), 148-170.

Griffin, A. (1997). The effect of project and process characteristics on product development cycle time. Journal of Marketing Research, 34(1), 24-35.

Gurdon, M. A., \& Samsom, K. J. (2010). A longitudinal study of success and failure among scientist-started ventures. Technovation, 30(3), 207-214.

Harrison, R. T., Cooper, S. Y., \& Mason, C. M. (2004). Entrepreneurial activity and the dynamics of technology-based cluster development: the case of Ottawa. Urban Studies, 41(5-6), 1045-1070.

Hastie, T., Tibshirani, R., \& Friedman, J. (2001). The elements of statistical learning: Data mining, inference, and prediction. New York: Springer.

Honig, B. (1998). What determines success? Examining the human, financial, and social capital of Jamaican microentrepreneurs. Journal of Business Venturing, 13(5), 371-394.

Kaasa, A. (2009). Effects of different dimensions of social capital on innovative activity: evidence from Europe at the regional level. Technovation, 29(3), 218-233.

Keller, G. (2005). Statistics for management and economics. Belmont: Thomson Brooks/Cole.

Klofsten, M., \& Jones-Evans, D. (2000). Comparing academic entrepreneurship in Europe - the case of Sweden and Ireland. Small Business Economics, 14(4), 299-309.

Klofsten, M., Jonsson, M., \& Simón, J. (1999). Supporting the pre-commercialization stages of technologybased firms: the effects of small-scale venture capital. Venture Capital, 1(1), 83-93.

Knockaert, M., Ucbasaran, D., Wright, M., \& Clarysse, B. (2011). The relationship between knowledge transfer, top management team composition, and performance: the case of science-based entrepreneurial firms. Entrepreneurship: Theory and Practice, 35(4), 777-803.

Kuhnert, P. M., Do, K.-A., \& McClure, R. (2000). Combining non-parametric models with logistic regression: an application to motor vehicle injury data. Computational Statistics \& Data Analysis, 34(3), 371-386.

Kuratko, D. F. (2005). The emergence of entrepreneurship education: development, trends, and challenges. Entrepreneurship: Theory \& Practice, 29(5), 577-597.

Lerner, J. (2005). The university and the start-up: lessons from the past two decades. Journal of Technology Transfer, 30(1/2), 49-56.

Levene, H. (1960). Robust tests for equality of variances. In I. Olkin (Ed.), Contributions to probability and statistics. Palo Alto: Stanford University Press.

Leydesdorff, L. (2000). The triple helix: an evolutionary model of innovations. Research Policy, 29(2), $243-255$.

Lo, A. W. (1986). Logit versus discriminant analysis: a specification test and application to corporate bankruptcies. Journal of Econometrics, 31(2), 151-178. 
Lynskey, M. J. (2008). The entrepreneurial university and spin-out firms in the UK. Industry \& Higher Education, 22(2), 81-98.

Morgan, B. B., Jr., \& Salas, E. (1993). An analysis of team evolution and maturation. Journal of General Psychology, 120(3), 277-291.

Mosey, S., \& Wright, M. (2007). From human capital to social capital: a longitudinal study of technologybased academic entrepreneurs. Entrepreneurship: Theory and Practice, 31(6), 909-935.

Mustar, P., Renault, M., Colombo, M. G., Piva, E., Fontes, M., Lockett, A., et al. (2006). Conceptualising the heterogeneity of research-based spin-offs: a multidimensional taxonomy. Research Policy, 35(2), 289-308.

Nahapiet, J., \& Ghoshal, S. (1998). Social capital, intellectual capital, and the organizational advantage. Academy of Management Review, 23(2), 242-266.

Nerkar, A., \& Shane, S. (2003). When do start-ups that exploit patented academic knowledge survive? International Journal of Industrial Organization, 21(9), 1391-1410.

Nicolaou, N., \& Birley, S. (2003). Academic networks in a Trichotomous categorisation of university spinouts. Journal of Business Venturing, 18(3), 333-359.

Ostgaard, T. A., \& Birley, S. (1996). New venture growth and personal networks. Journal of Business Research, 36(1), 37-50.

Packalen, K. A. (2007). Complementing capital: the role of status, demographic features, and social capital in founding teams' abilities to obtain resources. Entrepreneurship: Theory and Practice, 31(6), 873-891.

Parker, S. C. (2013). Do serial entrepreneurs run successively better-performing businesses? Journal of Business Venturing, 28(5), 652-666.

Pennings, J. M., Lee, K., \& van Witteloostuijn, A. (1998). Human capital, social capital, and firm dissolution. Academy of Management Journal, 41(4), 425-440.

Pirnay, F., Surlemont, B., \& Nlemvo, F. (2003). Towards a typology of university spin-offs. Small Business Economics, 21(4), 355-369.

Rasmussen, E., Moen, Ø., \& Gulbrandsen, M. (2006). Initiatives to promote commercialization of university knowledge. Technovation, 26(4), 518-533.

Reagans, R. E., \& Zuckerman, E. W. (2001). Networks, diversity, and performance: the social capital of corporate R\&D units. Organization Science, 12(4), 502-517.

Rocco, T. S., Bliss, L. A., Gallagher, S., \& Pérez-Prado, A. (2003). Taking the next step: mixed methods research in organizational systems. Information Technology, Learning, and Performance Journal, 21(1), 19-29.

Rosenblatt, D. M., \& Thelen, A. J. (1997). Entrepreneur-in-residence programs. Journal of Private Equity, 1(1), 37-47.

Rothaermel, F. T., \& Thursby, M. (2005). Incubator firm failure or graduation? The role of university linkages. Research Policy, 34(7), 1076-1090.

Rothaermel, F. T., Agung, S. D., \& Jiang, L. (2007). University entrepreneurship: a taxonomy of the literature. Industrial and Corporate Change, 16(4), 691-791.

Sapienza, H. J., \& Grimm, C. M. (1997). Founder characteristics, start-up process, and strategy/structure variables as predictors of shortline railroad performance. Entrepreneurship: Theory and Practice, 22(1), 5-24.

Schuller, T., \& Field, J. (1998). Social capital, human capital and the learning society. International Journal of Lifelong Education, 17(4), 226-235.

Schultz, T. W. (1961). Investment in human capital. The American Economic Review, 51(1), 1-17.

Shane, S., \& Stuart, T. (2002). Organizational endowments and the performance of university start-ups. Management Science, 48(1), 154-170.

Shrader, R., \& Siegel, D. S. (2007). Assessing the relationship between human capital and firm performance: evidence from technology-based new ventures. Entrepreneurship: Theory and Practice, 31(6), 893-908.

Siciliano, J. I. (1996). The relationship of board member diversity to organizational performance. Journal of Business Ethics, 15(12), 1313-1320.

Song, M., Podoynitsyna, K., van der Bij, H., \& Halman, J. I. M. (2008). Success factors in new ventures: a meta-analysis. Journal of Product Innovation Management, 25(1), 7-27.

Stinchcombe, A. L. (1965). Social structures and organizations. In J. G. March (Ed.), Handbook of organizations. Chicago: Rand McNally.

Tansey, R., White, M., Long, R. G., \& Smith, M. (1996). A comparison of loglinear modeling and logistic regression in management research. Journal of Management, 22(2), 339-358.

Tashakkori, A., \& Teddlie, C. (2003). Handbook of mixed methods in social \& behavioral research. Thousand Oaks: SAGE Publications Inc.

Terpstra, D. E., \& Olson, P. D. (1993). Entrepreneurial start-up and growth: a classification of problems. Entrepreneurship: Theory and Practice, 17(3), 5-20.

Unger, J. M., Rauch, A., Frese, M., \& Rosenbusch, N. (2011). Human capital and entrepreneurial success: a meta-analytical review. Journal of Business Venturing, 26(3), 341-358. 
van der Walt, N., \& Ingley, C. (2003). Board dynamics and the influence of professional background, gender and ethnic diversity of directors. Corporate Governance: An International Review, 11(3), 218-234.

Vanaelst, I., Clarysse, B., Wright, M., Lockett, A., Moray, N., \& S'Jegers, R. (2006). Entrepreneurial team development in academic spinouts: an examination of team heterogeneity. Entrepreneurship: Theory and Practice, 30(2), 249-271.

Vohora, A., Wright, M., \& Lockett, A. (2004). Critical junctures in the development of university high-tech spinout companies. Research Policy, 33(1), 147-175.

Watson, W., Stewart, W. H., Jr., \& BarNir, A. (2003). The effects of human capital, organizational demography, and interpersonal processes on venture partner perceptions of firm profit and growth. Journal of Business Venturing, 18(2), 145-164.

Welch, S. (1975). Sampling by referral in a dispersed population. The Public Opinion Quarterly, 39(2), 237245.

Wengraf, T. (2001). Qualitative research interviewing. London: Sage Publications.

Wetter, E., \& Wennberg, K. (2009). Improving business failure prediction for new firms: benchmarking financial models with human and social capital. Journal of Private Equity, 12(2), 30-37.

Wilkinson, A., \& Mellahi, K. (2005). Organizational failure: introduction to the special issue. Long Range Planning, 38(3), 233-238.

Wright, M., Lockett, A., Clarysse, B., \& Binks, M. (2006). University spin-out companies and venture capital. Research Policy, 35(4), 481-501.

Wright, M., Clarysse, B., Mustar, P., \& Lockett, A. (2007). Academic entrepreneurship in Europe. Cheltenham: Edward Elgar.

Youn, H., \& Gu, Z. (2010). Predicting Korean lodging firm failures: an artificial neural network model along with a logistic regression model. International Journal of Hospitality Management, 29(1), 120-127.

Yusof, M., \& Jain, K. K. (2010). Categories of university-level entrepreneurship: a literature survey. International Entrepreneurship Management Journal, 6(1), 81-96.

Zacharakis, A. L., \& Meyer, G. D. (2000). The potential of actuarial decision models: can they improve the venture capital investment decision? Journal of Business Venturing, 15(4), 323-346.

Zeithaml, V. A., Parasuraman, A., \& Berry, L. L. (1985). Problems and strategies in services marketing. Journal of Marketing, 49(2), 33-46. 